\title{
“Cada pessoa que passa em nossa vida deixa um pouco de si e leva um pouco de nós”: as experiências do fazer teatral vividas, sentidas e (com) partilhadas no GEPAT-Pessoas
}

Esta é uma pesquisa de mestrado em processo de finalização da dissertação que investiga o fazer teatral- que envolve processo de criação, pesquisa e extensão-do Grupo de Estudos e Práticas Artísticas Teatrais (GEPAT) - Pessoas, com ênfase na mediação teatral e abordagens teóricos-metodológicas da prática docente em Teatro, no contexto da Educação Técnica. O objetivo consistiu em analisar o fazer teatral das experiências vividas e suas contribuições tanto para o processo de ensino e aprendizagem quanto para a formação dos seus partícipes. A delimitação temporal compreende os anos de 2016 e 2017, período marcado pelas experiências vivenciadas em duas propostas pontuais: a oficina de teatro realizada por ocasião do movimento de ocupação na escola e a oficina de Teatro de Animação. O aporte metodológico está pautado na pesquisa narrativa e o lugar da percepção e da fala é o da docente pesquisadora e dos alunos/integrantes, tendo em suas narrativas, a possibilidade de construção textual com voz coletiva. As experiências vividas abordam os caminhos percorridos valorizando uma concepção de educação mais humana, em que os sujeitos aprendem com o saber (com)partilhado, respeitando os saberes e as necessidades dos sujeitos e percebendo que este processo de ensino e aprendizagem se realiza sem dissociar corpo e mente, sendo o corpo veículo e espaço de sensações e principalmente que teatro é vida que pulsa em corpos que a princípio teriam de tudo para serem simplesmente máquinas de depósito de aprendizagem.

Palavras-chave: Coletivo de teatro. Fazer teatral. Educação profissional técnica e tecnológica. Metodologias de ensino. Experiências.

This is a master's research in the process of completion of the dissertation that investigates the theatrical doing - which involves the process of creation, research and extension of the Group of Studies and Practical Theatrical Practices (GEPAT) - People, with emphasis on theatrical mediation and theoretical approaches -methodological aspects of the teaching practice in Theater, in the context of Technical Education. The objective was to analyze the theatrical performance of the lived experiences and their contributions both to the teaching and learning process and to the training of its participants. The temporal delimitation includes the years 2016 and 2017, a period marked by the experiences experienced in two specific proposals: the theater workshop held during the occupation movement at the school and the Animation Theater workshop. The methodological contribution is based on narrative research and the place of perception and speech is that of the researcher teacher and the students / members, having in their narratives the possibility of textual construction with a collective voice. The lived experiences approach the paths covered by valuing a more humane conception of 
education, in which subjects learn with shared knowledge, respecting the knowledge and needs of the subjects and realizing that this process of teaching and learning takes place without dissociating the body and mind, being the body vehicle and space of sensations and mainly that theater is life that pulsates in bodies that at the beginning would have of everything to be simply machines of deposit of learning.

Keywords: Theater collective. Make theatrical. Professional technical and technological education. Teaching methodologies. Experiences.

\section{AS EXPERIÊNCIAS DO FAZER TEATRAL VIVIDAS, SENTIDAS E (COM) PARTILHADAS NO GEPAT-PESSOAS}

O GEPAT teve suas atividades iniciadas em abril de 2012 e o nome Pessoas ${ }^{1}$ faz referência ao poema que trata sobre a passagem das pessoas nas nossas vidas e à valorização do material humano deste coletivo. Sendo composto por 16 alunos da educação profissional técnica e tecnológica, sob a coordenação da professora de Arte, com um fazer teatral pautado no processo de criação, pesquisa ${ }^{2}$ e extensão. Seu processo de criação é constituído por estudos teóricos e práticos, contemplando uma metodologia que aborde os aspectos da pedagogia teatral (KOUDELA; SANTANA, 2005).

Nosso foco de análise são as experiências vividas por este coletivo de teatro em duas oficinas de teatro: uma no movimento de ocupação dos estudantes na escola e outra, em teatro de animação-ministrada pelos membros do Projeto de extensão Casemiro $\mathrm{Coco}^{3}$ - em que estas atividades possibilitaram aos alunos uma vivência partindo do sentido da experiência teatral na escola, do jogo e da improvisação, enfatizando-se que teatro pode ser praticado por qualquer indivíduo. Destaca-se nesta caminhada “a possibilidade de pertencer-se uns aos outros e ao mesmo tempo poder ouvir-se-uns-aos-outros[...] estas experiências vividas nos oferecem a capacidade de reinventarmos” (TELLES, 2015, p.11-12). O ouvir-se-uns-aosoutros tornou-se primordial nestes tempos sombrios vivenciados principalmente de 2016 aos dias atuais, tempos de reformas na educação, no intuito de calar nossas vozes, mutilar nossos corpos, nossa mente.

1Ressaltando a essência da frase- "Cada pessoa que passa em nossa vida passa sozinha deixando um pouco de si e levando um pouco de nós”- pois a cada ano alguns integrantes saem da instituição deixando um pouco dele e levando um pouco de nós através das experiências vivenciadas no GEPAT.

2As atividades de pesquisa são vinculadas ao Grupo de Estudo e Pesquisa em Arte Educação-IFMA, com cadastro no Conselho Nacional de Pesquisa (CNPq).

3Este projeto funciona como um laboratório de pesquisa das linguagens expressivas dessa área específica do Teatro incluindo a coleta de fontes primárias e secundárias, cujos resultados são reelaborados e transformados em produtos de extensão, como cursos, oficinas, espetáculos, com publicações, exposições etc, oferecendo espaço de prática pedagógica para alunos das graduações da UFMA; professores de qualquer nível de ensino e também a alunos de cursos médios, técnicos etc. 
A pesquisa narrativa com ênfase nos estudos de Clandinin e Connely (2011) e de Cunha (2016) sobre as experiências das histórias vividas e contadas estruturou este estudo, sendo dividido em 04 etapas: 1-estudo teórico sobre fazer teatral na escola, 2-aplicação de prática teatral-realização de duas oficinas-, 3- pesquisa de campo para coleta das narrativas dos integrantes (diários de bordo, relatórios, poemas, vídeos e fotografias) e análise das experiências vividas e (com)partilhadas no intuito de compreender a relevância deste fazer teatral para os integrantes, como afirmam Tourinho e Martins (2016, p.124) “Ao narrar um acontecimento, no fluxo cotidiano de relações e inter-relações, a pessoa tem a oportunidade de re-visitar e re-organizar sua experiência [...]”.

As experiências deste fazer teatral vividas, sentidas e (com) partilhadas possibilitaram ressignificar a aprendizagem em Teatro neste ambiente tecnicista, em que o processo de criação, a pesquisa e a extensão constituíram a base de uma metodologia de ensino, valorizando-se olhar o outro, reconhecendo o corpo no teatro como elemento propulsor uma aprendizagem significativa, respeitando os educandos, seus saberes e suas lutas diárias, explorando a aquiescência do seu cotidiano e do mundo a sua volta.

CLANDININ, D. Jean. CONELLY, F. Michael. Pesquisa narrativa: experiências e história na pesquisa qualitativa. Tradução: Grupo de Pesquisa Narrativa e Educação de Professores ILEEL/UFU. Uberlândia: EDUFU, 2011.

CUNHA, Maria Isabel da. Conte-me agora! As narrativas como alternativas pedagógicas na pesquisa e no ensino. Disponível em $<\underline{\text { http://www.scielo.br/scielo.php? }}$ script=sci arttext\&pid=S0102-25551997000100010> Acesso em 12/02/2016.

KOUDELA, Ingrid.D. SANTANA, Arão.P.de. Abordagens Metodológicas do Teatro na Educação. In: Ciências Humanas em Revista-São Luís, V.3, n.2, dezembro de 2005.

TELLES, Narciso. Ainda é tempo de miragens/Prefácio. In: BARRETO, Cristiane Santos. A travessia do narrativo para o dramático no contexto educacional. São Paulo: Paco Editorial, 2015.

TOURINHO, Irene; MARTINS, Raimundo. (Des) arquivar narrativas para construir histórias de vida ouvindo o chão da experiência. In: SOUZA, Elizeu; TOURINHO, Irene; MARTINS, Clementino de. (Orgs). Pesquisa Narrativa: interfaces entre histórias de vida, arte e educação. Santa Maria/RS: Editora da UFSM, 2016. 